\title{
NSF puts big money into complex ecology
}

Colin Macilwain, Washington

When marine biologist Rita Colwell, newly appointed head of the US National Science Foundation (NSF), announced in 1998 that 'biocomplexity' would be a priority for the agency, many scratched their heads and wondered what the word meant.

The meaning of her commitment, if not the word itself, became clearer last week when the NSF handed out $\$ 52.5$ million of grants for multidisciplinary ecological studies.

The 16 main awards, each worth between $\$ 1$ million and \$4 million, are remarkably large for university ecologists, even in the United States. Their award represents an important breakthrough for a discipline whose practitioners say they have rarely had the resources they need to do large studies.

"This is going to change our culture," says Diana Wall, an expert in soil biodiversity at Colorado State University, Fort Collins, and former president of the Ecological Society of America (ESA). "For the first time, ecology will be linked with other disciplines to study large and complex environmental problems."

One award will go to Stephen Carpenter of the University of Wisconsin at Madison, the current ESA president. With four others, he will get almost $\$ 3$ million to study the interactions of people, land and water on lake shorelines.

Carpenter says that, in preparing the grant application, the team spent much of its time working out just how the project should address complexity. Their eventual proposal was to determine whether it is better to use a complex model for lakeshore ecosystems, or whether a conventional, linear approach will suffice.

Whereas some grants are for studying broad ecosystem questions, others cover specific environmental problems. Alan Hastings and four colleagues at the University of California at Davis, for example, will receive $\$ 4$ million to study the impact of the invasive cordgrass Spartina alterniflora on America's Pacific coast.

Lest ecologists worry that the money is a flash in the pan, the NSF is also supporting 57 'incubation activities', which will allow groups of researchers with common interests to get to know each other and plan projects for the future.

As the grants were released, Congress agreed on a 2001 budget for the NSF that includes $\$ 75$ million for biocomplexity. This is a rise of $50 \%$ compared with this year, but is well short Colwell's request for $\$ 136$ million (see page 827). Agency officials hope to request proposals for this money as soon as next month.

The biocomplexity initiative is part of a broader push, recommended last year by the

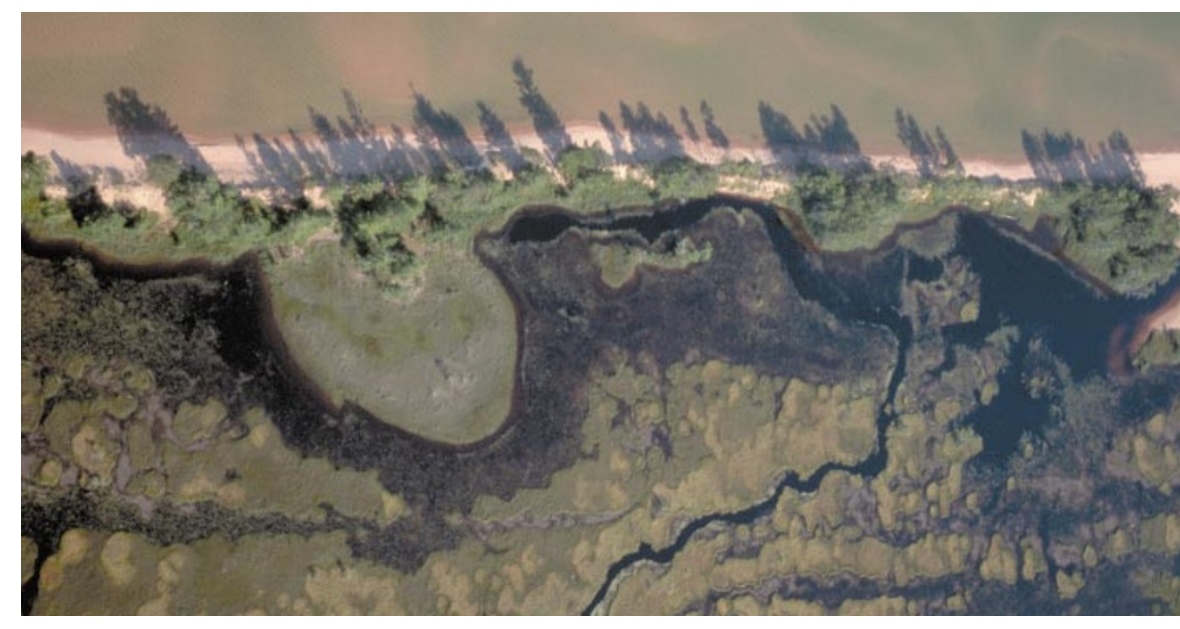

The big picture: a Wisconsin lakeshore, subject of one 'biocomplexity' project.

National Science Board, to increase the NSF's support for environmental science by as much as $\$ 1$ billion a year. But the Congress's move to cap biocomplexity's growth indicates that this is likely to be easier said than done.

http://www.nsf.gov/home/crssprgm/be/

biocomp-init/bcawd00.htm

\section{Deep roots of Nazi science revealed}

\section{Alison Abbott \& Quirin Schiermeier, Munich} A Berlin-based group of science historians has found that the ties between the top German scientists whose research was used to justify Nazi policies and the regime itself were much closer than was once thought.

In 1939, for example, Heinrich Himmler, the head of the Gestapo, praised two leading researchers at the Kaiser Wilhelm Institute (KWI) for Anthropology in Berlin for their work "that has contributed significantly to the scientific recognition of the racial parts of the national socialist view of the world".

The historians' report was published last week. Their research on the history of the Kaiser Wilhelm Society (KWS) from 1933 to 1945 is being funded by the Max Planck Society (MPS), its postwar successor.

Responding to the report, Hubert Markl, president of the MPS said: "There is no way of denying that directors, scientists and research assistants in many biomedical Kaiser Wilhelm Institutes put themselves in the service of a criminal regime. They actively supported measures conflicting with human rights and exploited the opportunities to use science conducted beyond all morally acceptable limits for the benefit of their own research."

Markl said he felt "deep disgust for the way that unscrupulous research was carried out" and appealed to German biomedical researchers to "confront and discuss their pact"

(e) 2000 Macmillan Magazines Ltd

The group has found that Ernst Rüdin, director of the KWI for Psychiatry in Munich, and Ernst Fischer and Otmar von Verschuer, both of whom headed the KWI for Anthropology in Berlin during the Third Reich, advised the Nazis at the highest levels.

All three had direct contact with the Nazi leadership and served on important government advisory panels. Rüdin, along with his co-worker Fritz Lenz, sat on an expert committee to the ministry of the interior on population and race policies.

Research into the links between KWS scientists and the Nazi regime dates back to the early 1980s. But the Berlin group is the first to investigate the direct influence of contemporary anthropological and biomedical research on the Nazi's racial and medical legislation.

Historians knew that Rüdin, whose work to give race laws a scientific basis was funded directly from Hitler's office, had chaired the committee's working group on 'racial hygiene and racial policies'. This panel set the criteria for the castration of criminals and the forceable sterilization of so-called inferior women, particularly those with 'psychological' problems.

The report says that Rüdin lobbied successfully for ever broader criteria. On his initiative, the sterilizations came to include the 'morally ill' — Nazi-speak for the mentally handicapped. This category covered $95 \%$ of the 400,000 sterilizations carried out between 1933 and 1945.

At Rüdin's suggestion, the sterilized 
included 600 children of black French soldiers and German women in the state of Rhineland, which the French occupied after the First World War.

In 1937, von Verschuer was made an expert to the Research Department on Jewish Questions of the governmental Reich's Institute for the History of the New Germany, whose main role was to research 'world Jewry'.

In this capacity, he wrote to Fischer that it was "important that our race policies, including the Jewish question, develop an objective scientific background that is broadly accepted".

The historians have not yet been able to show whether Nobel laureate Adolf Butenandt, director of the KWI for Biochemistry in Berlin and a postwar president of the MPS, allowed blood samples from Auschwitz to be analysed at his institute (see Nature 403, 474-475; 2000). But they argue that it is unlikely that he did not know about the work being done under his directorship.

The historians have so far focused on four institutes. Three of these were considered biological; the fourth was the KWI for Metal Research in Stuttgart.

It is not known whether Nazi sympathies were the exception or the rule among scientists, says Carola Sachse, the research group's head.

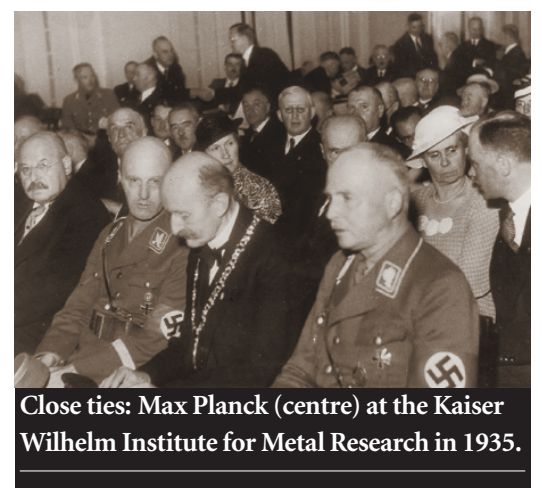

\section{US court slashes damages in polymerase- $\beta$ theft case}

Rex Dalton, San Diego

How much is academic research worth? For lab work that took nearly three years and produced papers in Science and Biochemistry the value is one US dollar, according to a California appeals court.

The ruling covers a lengthy battle over research on the rat DNA enzyme polymerase$\beta$, which was taken by La Jolla-based drugs company Agouron Pharmaceuticals from a federally funded laboratory at the University of California at San Diego (UCSD).

Last month, the state appeals court in San Diego upheld a 1998 jury verdict that in 1992 Michelle McTigue and her husband Jay Davies, both of Agouron, stole key elements of crystallography research from Huguette Pelletier, then a postdoc at UCSD (see Nature 393, 504; 1998). But the court reduced the jury's $\$ 200,000$ award to Pelletier to $\$ 1$, ruling she had not proved any damage.

Formerly a crystallographer at Baylor College of Medicine in Houston, Texas, Pelletier left science last year, largely in frustration over the incident. She now works for a Los Angeles community-service organization.

The decision highlights the dilemma faced by university scientists trying to protect their research from the representatives of biotech companies who walk round university labs seeking leads to develop into products.

Pelletier will appeal to the California Supreme Court against last month's verdict. She hopes to create a legal precedent affirming the value of academic research.

She has written to the Bruce Alberts, the president of the National Academy of Sciences, asking him to file documents with the California Supreme Court on the value of academic research and the damage caused by scientific misconduct.

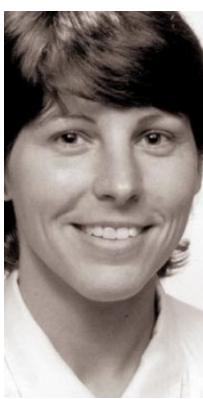

Pelletier: will appeal against the verdict.
"It is difficult under existing laws to place a dollar value" on research such as Pelletier's, says her attorney, Daniel MacLeod. The $\$ 200,000$ originally awarded was based on a year's grant from the National Institutes of Health, which funded the lab where she worked at UCSD.

Academic scientists who are victims of this sort of practice have to seek redress under laws designed for misappropriation of commercial and patented data, MacLeod says. And as the reward system for academic researchers involves a range of factors, including publication and academic promotion, he adds, it is difficult to demonstrate damage.

Mike Varney, vice-president for research at Agouron, now owned by the drugs company Pfizer, issued a statement saying that the company "continue[s] to fully support the integrity of our scientists and the appropriateness of their conduct."

Pelletier filed her lawsuit in 1994. She contended that McTigue, a former doctoral student at UCSD, used her access to the university to secure techniques on crystallography on rat polymerase- $\beta$. These were then given to Davies for his Agouron project to try to develop a cancer medication from the enzyme, which repairs DNA.

The project was eventually abandoned. But Davies, McTigue and others used the data for the first publication of the rat polymerase$\beta$ crystal, which appeared in Cell in 1994. Pelletier's work on polymerase- $\beta$ was later published in Science and Biochemistry.

\section{Canada plans reduction in greenhouse-gas emissions}

David Spurgeon, Montreal

A month before the next large intergovernmental meeting on climate change, to take place in The Hague in the Netherlands, the Canadian government has announced that it will cut emissions of greenhouse gases by about $\mathbf{6 5}$ million tonnes per year over the next five years. This would take it one-third of the way towards the target agreed at the previous climate meeting in Kyoto.

The government will spend up to Can $\$ 500$ million (US\$330 million) on cutting emissions from transport, energy production, industry, buildings, forestry and agriculture, international projects, technology and science. Together these activities account for more than $\mathbf{9 0 \%}$ of the total.

Since 1995, Canada has spent Can $\$ 850$ million on climate change, but its greenhouse-gas emissions have continued to rise. An Environment Canada report found that they were 13\% higher in 1998 than in 1990.

Canada's Kyoto target is to cut the $\mathbf{1 9 9 0}$ figune by $6 \%$ by $2008-12$. According to the government figures, this will mean a reduction of some 200 million tonnes. Canada's "Action Plan 2000 on Climate Change" promises that the government will buy as much as $20 \%$ of its electricity from renewable sources such as wind and solar power. It also includes incentives to stimulate sales of renewable energy and a tripling of the amount of ethanol the country produces annually.

The plan will be taken to a meeting with the provinces later this month in Quebec City in an attempt to convince them to make similar commitments in advance of the meeting in The Hague. 